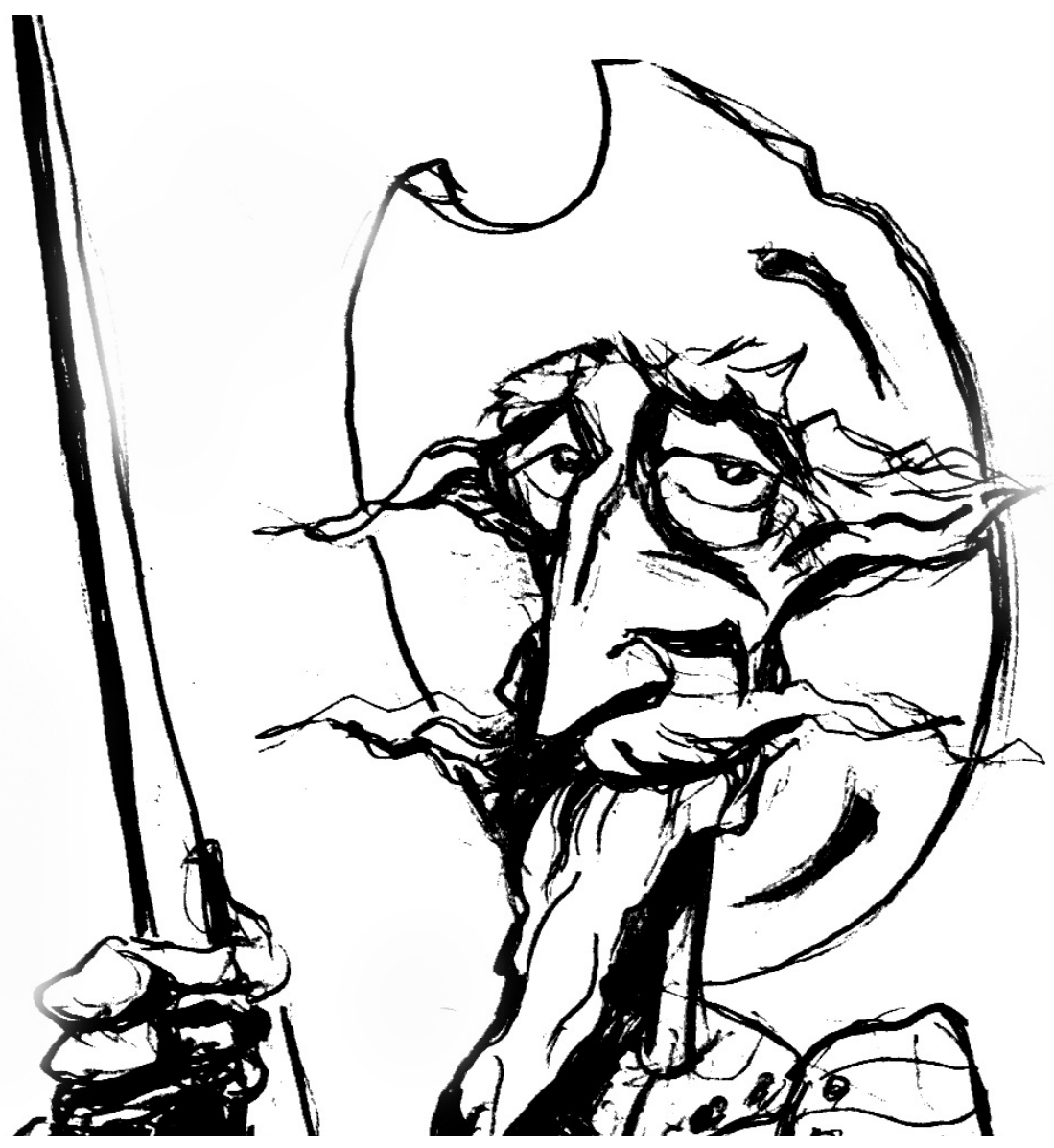

Entre la escuela y la prensa. Primeras experiencias de organización sindical docente en Mendoza (1919)

[Matías Latorre Carabelli] 



\title{
Entre la escuela y la prensa. Primeras experiencias de organización sindical docente en Mendoza (1919)*
}

\author{
Between the School and the Press. First Experiences of Teachers' Union \\ Organization in Mendoza (1919)
}

\author{
MATIAS LATORRE CARABELLI
}

\begin{abstract}
Resumen
El siguiente trabajo propone analizar en perspectiva de género y clase, los orígenes de la Agrupación IDEA y su relación con la primera organización sindical del magisterio, Maestros Unidos, durante los meses de abril y mayo de 1919 en la provincia de Mendoza. Se analizan los objetivos fundacionales de ambas organizaciones y su ingreso en la Federación Obrera Provincial local y en la Federación Obrera Regional Argentina (IX Congreso) a nivel nacional. También se pretende dar cuenta de las transformaciones en el proceso de identificación de las maestras mujeres en conflicto, mediante un análisis cualitativo del modo en que lo femenino se hace presente discursivamente en la revista cultural-gremial IDEA, en los inicios del largo conflicto que mantuvo el magisterio mendocino con el gobierno durante 1919.
\end{abstract}

\section{Palabras clave}

Clase; género; magisterio; maestras; Mendoza 1919

\begin{abstract}
The following work proposes to analyze from a gender and class approach, the beginnings of the IDEA Group and its relationship with the first teachers' union organization, United Teachers, during the months of April and March 1919 in the province of Mendoza. We analyze the founding objectives of both organizations and their entry into the local Provincial Workers Federation and into the Argentine Regional Workers Federation (IX Congress) at the national level. We also intend to account for the transformations experienced by women teachers in conflict in their process of identification, through a qualitative analysis of the way in which the feminine is present discursively in the cultural-gremial magazine IDEA, at the beginning of the long conflict between this union and the provincial government during 1919.
\end{abstract}

Key Words

Class; gender; teaching; teachers; Mendoza 1919

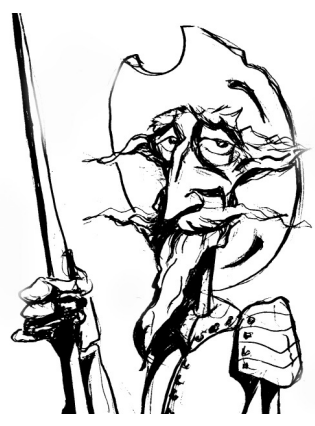

Recibido con pedido de publicación el 15 de julio de 2019

Aceptado para su publicación el 5 de octubre de 2019

Versión definitiva recibida el 22 de noviembre de 2019

Matías Latorre Carabelli, Universidad Nacional de Cuyo, Mendoza, Argentina; e-mail: calibanesco@gmail.com

\footnotetext{
* Agradezco los comentarios y sugerencias de las/los evaluadores de esta publicación.

Esta obra se publica bajo licencia Creative Commons. Atribución-NoComercial-CompartirIgual $($ (c) EY-NC-SA 4.0 Internacional
}

Carabelli Latorre, Matías “Entre la escuela y la prensa. Primeras experiencias de organización sindical docente en Mendoza (1919)", Prohistoria, Año XXII, núm. 32, dic. 2019, pp. 97-126 


\section{Introducción}

En agosto de 1919, La Organización Obrera, periódico oficial de la Federación Obrera Regional Argentina (IX Congreso), informaba a sus afiliados sobre el grado de movilización y organización alcanzada por el magisterio mendocino en lucha contra el gobierno de la provincia:

"se concibe la huelga de maestros como una magnífica exteriorización de resistencia y solidaridad tanto más digna de aplauso cuanto son mujeres en este caso las que se atreven a la lucha más terrible que haya memoria en la provincia". ${ }^{1}$

El relato daba cuenta de la agitación social que las huelgas docentes habían generado tanto a nivel provincial como nacional y, con asombro, hacían hincapié en dos características muy poco usuales observadas en los conflictos sociales de la época: primero, la adopción de la huelga como forma de lucha docente y, segundo, que esa lucha estuviera bajo la dirección de mujeres/maestras organizadas sindicalmente. Efectivamente el largo conflicto del magisterio mendocino acaecido durante la casi totalidad del año 1919, dejaba un saldo de más de 100 días de huelgas magisteriales y, en sus dos momentos de mayor confrontación con el Estado, lograban declarar junto al movimiento obrero organizado provincial dos huelgas generales solidarias que paralizaron la provincia. $^{2}$

Precisamente en este trabajo nos preguntamos por los orígenes de este movimiento que conmocionó a la provincia y al país. Si bien, a la fecha contamos con varios y valiosos estudios que han analizado distintos aspectos del largo conflicto del magisterio mendocino en 1919, deseamos que este artículo contribuya a habilitar otros sentidos a partir de inquietudes que no han sido abordadas por los estudios realizados sobre este caso, sobre todo el relativo al estudio de las transformaciones en el proceso de identificación experimentadas por las mujeres maestras organizadas sindicalmente durante el conflicto. La bibliografía existente sobre la temática ha sido elaborada, desde diversos ámbitos, militante, periodístico y académico, por Benito Marianetti (1970: 69-89), Jacinto De la Vega (1997), Graciela Crespi (1997), Rodolfo Richard Jorba (2014a) y por Ana Luisa Dufour y Stella Mazzei (2007). En términos generales, estos apuntan a la descripción del conflicto en sus dimensiones políticas y sociales, a excepción del realizado por Crespi, en el que la autora vuelca una mirada desde una perspectiva de género, que es abordada y asumida como puntapié inicial para la realización de nuestro escrito, cuya intención es la de enriquecer dicha perspectiva a partir de otros interrogantes y

\footnotetext{
${ }^{1}$ La Organización Obrera (9 de agosto de 1919), citado en Crespi, 1997: 167.

${ }^{2}$ La primera huelga general fue declarada el 4 de agosto y se extendió durante 8 días. La segunda comenzó el 30 de septiembre (cuando el magisterio sumaba 87 días de huelga) y se extendió por 7 días.
} 
de la incorporación de nuevas fuentes documentales. En todos los casos restantes, la dimensión de género del conflicto se encuentra apenas señalada. Los/as autores/as mencionados/as resaltan la mayoritaria participación femenina en términos cuantitativos, pero no avanzan en interpretaciones críticas que puedan dar cuenta del carácter feminizado que adquiere el conflicto (transformaciones en la subjetividad de las maestras en lucha, construcción de nuevas identidades sociales, entre otras). Es por ello que esta propuesta interpretativa añade nuevas lecturas que permiten complejizar el carácter neutro-masculino con el que se ha analizado la historia de la agrupación IDEA y la organización sindical "Maestros Unidos", protagonistas indiscutibles de este conflicto. Nuestra propuesta parte de estas premisas: releer los conflictos del magisterio desde el cruce de las preocupaciones de la historia social del trabajo y de la teoría feminista ya que estamos convencidos que dicha articulación permitirá observar a nuevos sujetos sociales, nuevas prácticas, nuevos problemas y aristas estructurales del conflicto que emergen a partir de la utilización de estas claves interpretativas. ${ }^{3}$

Como advertimos con anterioridad, nos abocaremos al análisis del momento inicial de ese gran conflicto. Para ello hemos tomado un breve recorte histórico (marzo-abril-mayo) al que consideramos central y hemos denominado "primera fase". Lo abordaremos, fundamentalmente mediante un análisis cualitativo del modo en que lo femenino se hace presente en la revista quincenal de la Agrupación, también denominada IDEA. ${ }^{4}$ Para ello tomaremos solo los primeros números que se corresponden temporalmente con la denominada primera fase del conflicto. La selección responde a que en estos se advierten importantes cambios en algunos de los aspectos identitarios de este colectivo de maestras. En esa identidad se juegan múltiples dimensiones, en la que si bien, todas son parte de este constructo y en este sentido inescindibles, pretendemos a modo de ensayo analítico, distinguirlas y jerarquizarlas en función de ordenar y orientar nuestro trabajo.

En este sentido, se analizan rupturas y continuidades en la experiencia laboral y organizacional de este colectivo de maestras con la intención de responder a los siguientes interrogantes generales a partir la incorporación de nuestra fuente principal (IDEA):

a. Dimensión de género: ¿Cómo operó la feminización del magisterio provincial al momento de enunciar sus reclamos? ¿Qué lugar cupo a las relaciones entre los géneros y cómo se percibieron a sí mismas las maestras mendocinas organizadas sindicalmente y en lucha durante la

\footnotetext{
3 Para la combinación de ambas perspectivas hemos seguido fundamentalmente la línea de trabajo planteada en Andújar, 2016.

${ }^{4}$ Este quincenario se publicó entre los meses de abril de 1919 y julio de 1920. Durante ese lapso se publicaron 21 números. Dicho periódico gremial fue elaborado por un grupo, que en su gran mayoría estuvo compuesto por maestras.
} 
primera fase del conflicto del magisterio de 1919? ¿De qué modo jugaron los preceptos religiosos y nacionales vinculados a la labor docente durante el conflicto a partir del carácter misional y el apostolado laico en relación con la feminización de la tarea docente?

b. Dimensión de clase: ¿Qué cambios y continuidades operaron a partir de la adopción sindical como forma de organización del gremio docente? ¿Con qué clase social plantearon pertenencia antes y después de la primera huelga del magisterio? ¿Qué tipo de alianza se propusieron desde "Maestros Unidos" con la Federación Obrera Provincial durante el desarrollo del conflicto? ¿Qué tipo de adecuaciones se produjeron sobre los modos clásicos y masculinizados de lucha sindical a partir de la incorporación de este colectivo feminizado a la Federación Obrera? ¿Qué implicancias sociales tuvo para las maestras la ocupación del espacio público durante la huelga? ¿Qué tipos de vinculación social se establecieron con las/los estudiantes, sus familias y las demandas del hogar obrero?

c. Dimensión estratégica de las clases dominantes y el Estado provincial: ¿Qué dispositivos represivos impulsaron las clases dominantes y el Estado para lograr el mantenimiento del orden? Si la protesta encabezada por maestras tensionó las prescripciones estatales paternalistas y patriarcales ¿Existieron formas particulares de coerción estatal a raíz de la composición mayoritariamente femenina del gremio en lucha?

\section{Antecedentes y descripción de la primera fase del conflicto (marzo-mayo de 1919)}

Si bien este trabajo no pretende ahondar pormenorizadamente en los antecedentes vinculados con el surgimiento de la agrupación IDEA y Maestros Unidos (en adelante, MU), el primer sindicato docente de la provincia de Mendoza, consideramos pertinente señalar algunos de los asuntos que nos parecen cruciales para nuestra investigación. En este apartado presentamos una breve reconstrucción de los antecedentes organizativos del magisterio mendocino para luego adentrarnos en nuestro tema.

La primera organización gremial del magisterio que existió en Mendoza se llamó: Asociación de Maestros. Su origen se remonta al año 1904 y se caracterizó por su forma de organización mutualista en la que se agruparon docentes pertenecientes al ámbito nacional y provincial. La conducción fue ejercida por docentes nacionales mientras que la composición mayoritaria de maestros pertenecía a la órbita provincial, quienes solo lograron una representación minoritaria en algunas vocalías de la comisión directiva (Crespi, 1997: 152). La discriminación económica fue otra de las características determinantes para las/los docentes provinciales ya que el pago de los salarios 
dependía del presupuesto provincial y eran inferiores al de sus pares nacionales. En diversas oportunidades ni siquiera fueron erogados, los atrasos en la liquidación de sus haberes se calculaba entre los 8 y 12 meses. Existen coincidencias en las investigaciones mencionadas en reconocer que la dirección de la Asociación fue "conservadora" y poco efectiva al momento de solucionar estos problemas, aunque es justo decir que estamos ante una institución que ha sido poco investigada.

Los primeros conflictos docentes se remontan a los gobiernos liberal conservadores, y en particular, el que ejerció Francisco Álvarez entre 1914-1918. Durante este período ocupó el cargo de Director General de Escuelas el Dr. Lucio Funes. Múltiples problemas fueron los que tuvo que asumir y denunciar el gremio docente, los más comunes se relacionaron, como ya mencionamos, con el atraso en el pago de los salarios, la designación arbitraria de docentes e inspectores por parte de funcionarios del gobierno, la "anarquía" institucional debido a la ausencia de una Ley de Educación que reglamentara el sistema educativo y el desvío de subsidios nacionales que debían ser destinados al magisterio y que fueron empleados para otros fines por el Estado provincial, entre otros (Dufour y Mazzei, 2007; De la Vega, 1997).

En enero de 1918, se celebraron las elecciones para la gobernación de la provincia y triunfó de manera contundente la fórmula radical de José Néstor Lencinas-Delfín Álvarez. El radicalismo local construyó una identidad política y cultural que presentó como sus principales enemigos a los miembros de la oligarquía (Mellado, 2007: 18). Según esta caracterización el régimen oligárquico fue perdiendo terreno a favor de la democratización sobre la base del liderazgo personalista o mesiánico de Lencinas (Olguín, 1965; Lacoste, 1995; Luis, 2015). En este sentido, J. N. Lencinas lideró lo que algunos autores, como Rodolfo Richard Jorba, denomina como populismo temprano o liberal. ${ }^{5}$

Desde un inicio el gobierno radical instrumentó medidas legales y político-sociales tendientes a abordar los reclamos de las clases populares. ${ }^{6}$ Aun así, para las/los docentes provinciales la situación continuó siendo apremiante.

En marzo de 1918 Lencinas nombró a Enrique Julio como Director General de Escuelas (DGE). Se trataba de un maestro y periodista radical de Bahía Blanca, que al momento de asumir se encontraba sin vinculación con el

\footnotetext{
${ }^{5}$ Para un análisis en esta perspectiva se recomienda ver Richard Jorba, 2014b.

${ }^{6}$ Las leyes a las que nos referimos son: 1) Ley 731 (diciembre de 1918) crea la Inspección General del Trabajo: para el cumplimiento de la legislación laboral y asesoramiento de los obreros. También regulaba el trabajo de mujeres y niños de hasta 14 años. Puesta en funcionamiento efectivo a partir de 1922, durante el gobierno de Carlos Washington Lencinas; 2) Ley 732 (diciembre de 1918) establecía: Jornada de 8 hs. y salario mínimo (para estatales fundamentalmente en este período); 3) Ley 716 (julio de 1918): se creaba la caja de jubilaciones para el personal del Estado; y 4) Ley 717 (julio de 1918): Creación de la caja de Jubilaciones y de Vida para el personal de la DGE (Luis, 2015).
} 
ámbito educativo y que poco contribuyó al mejoramiento del sector. Al inicio de su gestión llevó adelante reestructuraciones de la repartición escolar y la reorganización del cuerpo de inspectores (Richard Jorba, 2014a: 97). Con la aplicación de esas medidas quedó excluida del cargo de inspectora la prof. Florencia Fossatti ${ }^{7}$ sin mediar explicación alguna. Esto dio lugar a protestas del magisterio mendocino para lograr su reincorporación. A partir de ese momento, Fossatti se fue transformando en una fortísima referente del movimiento gremial docente.

Los reclamos docentes continuaron aglutinándose disruptivamente en torno a la inestabilidad laboral y jubilatoria, la desprotección legal, y el atraso "crónico" en el pago de los salarios de las/os maestras/os, que para ese entonces sumaba 8 meses. Esta alarmante situación tampoco fue atendida por el nuevo gobierno radical. A mediados de marzo de 1919 un grupo de maestras pertenecientes a la Asociación de Maestros decidieron conformar una agrupación y lanzaron el 13 de abril el primer número de la revista IDEA, de tirada quincenal. Ante su aparición pública, el gobierno escolar resolvió la suspensión por quince días, sin goce de sueldo, de las catorce personas que integraban la agrupación y el comité editorial de la revista, bajo amenaza de ser cesanteadas en caso de continuar con las actividades de la organización. En respuesta al accionar gubernamental, las/os maestras/os de la Capital mendocina se reunieron en asamblea en el Orfeón Español el día 26 de abril en la que 180 docentes resolvieron "protestar en forma terminante" y "exigir la reposición de los miembros del magisterio afectados por la resolución de la dirección general de Escuelas" ${ }^{8}$ En ese mismo acto se votó en forma unánime la creación del sindicato "Maestros Unidos" y a la principal responsable de la nueva entidad gremial, Florencia Fossatti. Pasados dos días de su fundación, ingresó a la Federación Obrera Provincial (FOP) e inmediatamente se incorporó a la Federación Obrera Regional Argentina (FORA) del IX Congreso, de corte sindicalista. De ese modo se convirtió en el primer sindicato docente de Argentina en ingresar a una Central Obrera.

Una vez más, la reacción del gobierno escolar no se hizo esperar. En forma casi simultánea, un día antes del acto inaugural que diera nacimiento a Maestros Unidos, se creó la entidad gremial “Unión Mendocina de Maestros”, sindicato paralelo y oficialista carente de prensa propia pero que mantuvo

\footnotetext{
7 Florencia Fossatti "la distinguida y prestigiosa profesora ya había sido objeto antes de una medida semejante bajo la dirección de don Manuel Antequeda. Luego había sido reincorporada como inspectora de bibliotecas y luego, como inspectora seccional" (Marianetti, 1970: 71-72). Resaltamos la situación atípica en la que una mujer ocupase cargos jerárquicos destinados mayoritariamente a varones. Sobre una historia de las ideas pedagógicas de Fossatti en clave femenina ver Alvarado, 2016.

8 Los Andes (27 de abril de 1919), citado en Crespi, 1997; Marianetti, 1970: 71-72.
} 
fuertes vínculos con la revista Patria. ${ }^{9}$ Además, se procedió a la suspensión de las/los 180 docentes que habían refrendado con su firma el acta de MU y a la clausura de varias escuelas de la capital que, so pretexto de reorganización, ponía en evidencia la falta de personal para atender el normal funcionamiento institucional. Este accionar gubernamental agudizó el conflicto. Estalló la huelga del magisterio y las manifestaciones callejeras en repudio a las resoluciones llevadas adelante por el gobierno. La escuela se daba cita en las calles céntricas mendocinas: junto a "las señoritas" maestras marcharon sus estudiantes y diversas organizaciones obreras. La movilización integrada por "unos cien niños" al pasar frente al diario oficialista La Montaña, fue reprimida a balazos dejando un saldo de cuatro niños heridos lo que provocó aún mayor indignación entre los/las manifestantes y la comunidad. ${ }^{10}$

Para finalizar esta primera fase cabe señalar que el conflicto entró en un impasse a partir del 3 de mayo, mediante la intervención federal de la Dirección General de Escuelas, ejecutada por el interventor Dr. Perfecto Araya, quién optó por el alejamiento de Enrique Julio de la dirección escolar. Ocupó su lugar Eduardo Luzuriaga, quien procedió a dejar sin efecto las medidas tomadas por su antecesor. Las y los maestros/as suspendidas/os fueron restituidas/os en sus lugares de trabajo -a excepción de Florencia Fossatti-. En ese momento se le dio curso, en parte, a otro de los pedidos realizados por Maestros Unidos, que pretendía que el nuevo gobierno escolar desplazara de sus cargos a funcionarios implicados en las resoluciones contra las/os docentes y cercanos a Enrique Julio: el secretario, subsecretario e inspector general. ${ }^{11} \mathrm{Si}$ bien, como mencionamos anteriormente, el largo y profundo conflicto del magisterio mendocino continuó hasta, por lo menos, el mes de enero de 1920, esta primera fase culmina con una victoria parcial por parte de la nueva organización del magisterio.

\section{Sumar y restar: visibilización y victimización}

La revista IDEA fue la "la chispa que prendió la mecha",12 al decir de sus propias realizadoras. Dada la centralidad que tuvo para sus protagonistas como medio de expresión, para este trabajo se constituye en la fuente principal, ya que se condensa en ella múltiples posibilidades de abordaje como documento gremial, político, educativo, pedagógico, cultural, económico, entre otras. Esta

\footnotetext{
${ }^{9}$ El 28 de abril, maestros/as reunidos en asamblea designan como su presidenta a Isabel Garay (De la Vega, 1997: 48). Es muy poca la información recolectada sobre esta organización y la vinculación con Patria. Justamente, por ello, nos encontramos abocados a ampliar la pesquisa.

${ }^{10}$ Cfr. diario Los Andes (1 de mayo de 1919), en el que realiza una crónica sobre la manifestación estudiantil del 29 de abril.

${ }_{11}$ Aunque el pedido de MU implicaba el desplazamiento, se accedió solo a la rotación del personal en otras reparticiones administrativas (De la Vega, 1997: 51).

${ }^{12}$ IDEA, año I (13 de mayo de 1919), núm. 3, p. 19.
} 
revista fue conformando un ámbito desde el que se pensó, se organizó, se discutió, se propuso y se renovó la forma organizativa del gremio y la educación en sus aspectos tanto político, cultural como pedagógico (Finocchio, 2009: 13). De este modo, nos proponemos indagar sobre las formas en que IDEA y MU interpelaron a un sector con capacidad creciente de generar opinión y tomar decisiones en la turbulenta situación de la que fue testigo y partícipe la naciente agrupación.

IDEA, se presentó en su primer número con fecha del 13 de abril de 1919, "ante la opinión" como un "órgano de publicidad portador de los ideales de un grupo de docentes" ${ }^{13}$ Desde un inicio la revista publicó en su primera página los principios rectores de la agrupación:

"1 Hacer efectiva la dignificación del maestro

$2^{\circ}$ Absoluta reserva de lo que se trate en las reuniones de los agrupados, responsabilizándose a cada uno de ellos de la acción que se desarrolle y sometiendo al juicio del público la actitud del que a ello falte, con la publicación de todos los antecedentes que motivaron su expulsión.

$3^{\circ}$ Aplaudir la acción de las autoridades escolares en sus actos de justicia, anatematizando toda irregularidad que lesione los intereses de la clase y que un análisis irrefutable compruebe.

$4^{\circ}$ Orientar por intermedio de su órgano de publicidad toda gestión escolar, ya sea en su faz técnica, ya en su forma administrativa.

$5^{\circ}$ Gestionar la ley de educación y defender el tesoro escolar y de jubilaciones

$6^{\circ}$ Ponerse por entero al servicio de estos fines, sin eludir trabajo y aportando como valores efectivos, fe, energía, puntualidad y constancia." 14

Estos principios fueron acompañados con los nombres y apellidos de quienes componían la agrupación y participaron del comité editorial de la revista. Sus responsables fueron:

Manuela Moyano de Biain, Luisa Duhagón, Zovehida Ávila, Margarita Ulloa, Tarsila Arias, Luisa Carreras, Tomasa Aguilar, María Gómez, Aida Correa Álvarez, Elena Ariza, María Paz Camardella, Josefa Capdevila, María del Rosario Sansano y Francisco Mercado Flores.

Seguidamente mostraremos las bases de MU y a sus integrantes para luego realizar una serie de comentarios que surgen a partir de su comparación.

\footnotetext{
${ }^{13}$ IDEA, año I (1919), núm. 1, p. 1

${ }^{14}$ IDEA, año I (1919), núm. 1, p. 1.
} 
Dejaremos para más adelante el análisis sobre el particular contexto que le dio origen, y los argumentos esgrimidos por la nueva Asociación. Por el momento recordemos que se conformó el día 26 de abril de 1919 luego de una importante asamblea que tuvo cita en el Orfeón Español. Su misión apareció publicada en el tercer número de IDEA (13 de mayo 1919) y versaba lo siguiente:

"1. ${ }^{\circ}$ Afirmar la personalidad moral del maestro; hacerla reconocer y respetar. Defender los intereses de cada uno de los miembros de la asociación.

2. ${ }^{\circ}$ Obtener el pago de sus haberes, el mejoramiento económico de la clase y la inversión del tesoro escolar y jubilaciones conforme a la ley.

3. ${ }^{\circ}$ Obtener la pronta sanción de la ley de educación y reforma de la de jubilaciones.

4. ${ }^{\circ}$ No tratar otros asuntos que no sean los de carácter profesional, desterrando en absoluto principios de partidos políticos y tendencias sectarias de cualquier clase o sistema."

Sus integrantes:

Florencia Fossatti, María del Rosario Sansano, Angélica Mendoza, María Sabella, Matilde Segura Urizar, Zovehida Ávila, Tarcila Arias, Amelia Blanco, Manuela Moyano de Biain, Sara de Baez, Cármen de Pérez, Francisco Mercado Flores y Blas Correa.

En cuanto a las similitudes programáticas se resaltan: la dignificación moral y material del magisterio, la defensa de los intereses de sus trabajadoras/es tanto de activos como pasivos; la reserva profesional, la independencia político partidaria y de sectarismos, la lucha por un marco legal que regulara la estabilidad de las/os maestras/os y de la educación provincial. Es importante aclarar que la alianza entre IDEA y MU quedó explícitamente sellada a modo de un contínuum indisoluble.

"IDEA atacada injustamente, ve levantarse en su torno la masa compacta que forma 'Maestros Unidos'. Ve vibrar al uniseno (sic) a sus compañeros que sienten como propia la ofensa inferida. $\mathrm{Y}$ en la palestra sucede a un grupo de catorce un conjunto de trescientos. IDEA ha sido la ocasión, la válvula de escape, la chispa que prendió la mecha, mecha tejida con injusticias y arbitrariedades amalgamadas con ocho meses de penuria económica, de necesidad profunda, que hicieron de la vida del maestro problema amargo e insoluble" ${ }^{15}$

${ }^{15}$ IDEA, año I (1919), núm. 3, p. 19. 
Unidad que parece reforzarse al analizar la composición de ambos organismos: MU se compuso de 13 integrantes, 11 mujeres y 2 varones. 5 de ellas/os fueron parte de ambas organizaciones. ${ }^{16}$

A partir de la información compartida hasta aquí, se nos hace necesario abrir un primer paréntesis. En la descripción que antecede a este apartado nos referimos a la existencia y conformación general del primer gremio docente, la Asociación de Maestros de la provincia de Mendoza. Entre ambas organizaciones asociadas se produjeron, al menos, tres transformaciones que las diferencian con dicha Asociación y que llaman poderosamente nuestra atención, a saber: 1) el relacionado al ámbito laboral: la totalidad de los miembros de IDEA y MU pertenecían a la repartición educativa provincial y no nacional, situación inversa a la que ocurría en la Asociación de Maestros. ${ }^{17}$ 2) en cuanto a las condiciones de trabajo: entendiendo que la pertenencia al ámbito provincial implicaba una fuerte discriminación económica -menor salario por igual trabajo, retraso en el pago de los salarios, especulación y usura por pagos realizados con vales de tesorería provincial, irregularidades en el manejo del presupuesto destinado al sistema educativo- y desprotección legal debido a la falta de una ley educativa que reglamentara y diera protección al sector-. 3) el concerniente a la dimensión de género abordado desde su faz cuantitativa: con excepción de un varón, la agrupación IDEA y su equipo editorial se conformó con una abrumadora mayoría femenina, una situación muy similar se dio en MU. Además, la dirección de IDEA quedó a cargo de una mujer maestra de origen española, María del Rosario Sansano y la presidencia de MU en manos de la profesora Florencia Fossatti. Estos puntos, nos permiten reconocer un diferencial histórico importante ya que hasta ese momento si bien la entidad gremial provincial existente estuvo conformada de manera combinada con miembros pertenecientes al ámbito nacional y provincial, no existen registros hasta IDEA y MU de haberse constituido organización del magisterio con una mayoría de maestras del nivel primario provincial y bajo su efectiva dirección. En cuanto al último punto, una aproximación de carácter cuantitativo nos ha permitido identificar a esta agrupación como un espacio feminilizado, punto de partida para un análisis que nos permita ir desentrañando el contenido femenino (feminizado) incluido en los discursos emanados de la organización a través de su revista ${ }^{18}$. Ello responde a que nuestra investigación pretende colocar en debate la categorización, supuestamente neutra, del género

\footnotetext{
${ }^{16}$ Ellas/os fueron: María del Rosario Sansano, Zovehida Ávila, Tarcila Arias, Manuela Moyano de Biain y Francisco Mercado Flores

${ }^{17}$ La presidencia de la Asociación estuvo a cargo del profesor Clodomiro Giménez -por ese entonces director de la escuela Normal Nacional mixta de Mendoza- y el Dr. Emilio Jofré como copresidente. José Vicente Ferrer y Zobehida Ávila ocupaban las secretarías (Marianetti, 1970: 71; De la Vega, 1997: 33).

${ }_{18}$ Para un análisis combinado sobre feminilización y feminización de la docencia, recuperamos los aportes de Yannoulas, 1993.
} 
masculino utilizado en el sustantivo "maestro". ${ }^{19}$ En ese sentido traemos a colación los sentidos diferenciados que la determinación de género otorgaba al docente, ya que no implicaba lo mismo ser maestro que maestra, ni por sus intereses ni por sus funciones, según el sexo delimitadas al interior del sistema educativo. Mucho menos por la valoración laboral e intelectual legítima y prestigiosa que tenía para la mujer maestra y no del todo equivalente para el maestro varón (Morgade, 1992; Yannoulas, 1996; Barrancos, 2007; Lobato, 2007; Garguin, 2014).

Retomando el análisis sobre IDEA, en la primera "redacción" 20 del quincenario realizaron la presentación de un programa de acción que se dirigió no solo a "colegas" sino que se proyectaba hacia "hombres cuya honradez moral individual les hace mirar con simpatía esta clase de movimientos". Es evidente que por el contexto adverso y urgente en el que emergió la agrupación percibieron que se encausarían por la vía de la lucha para el logro de sus objetivos: "La vida es lucha y ésta ha de ser ardua cuando ante ella se levanta como inexpugnable castillo, un cúmulo de disposiciones y reglamentos que todo lo exigen del educador a quien poco o nada conceden".

Se autodefinieron como grupo minoritario de avanzada y civilizado con amplias proyecciones de corte social.

"Pequeña vanguardia de voluntarios de una causa justa y noble envueltos en la bandera de la fe y del progreso, sabremos demostrar [...] que en la batalla hermosa de la cultura también las heridas enaltecen, los peligros se desprecian y la muerte glorifica" ${ }^{21}$

Los fines de la flamante agrupación fueron gremiales y educativos, pero también morales, estéticos, intelectuales, religiosos, patrióticos $\mathrm{y}$, finalmente, también sociales.

"IDEA tiene fines humanos: ella defenderá con entereza la causa del maestro; los tiene morales: tiende a su dignificación real y efectiva; los tiene intelectuales: velar por la enseñanza, propulsar el progreso; los tiene estéticos: elevar la mente del educador a lo bello y lo bueno, enseñándole a despreciar mezquindades y descartar egoísmos y finalmente, tiénelos también religiosos, ya que promete un culto, ferviente y constante, a la verdad, a la justicia y al sentimiento de patria,

\footnotetext{
${ }^{19}$ Una importante contribución en esta dirección se encuentra en los trabajos coordinados por Caldo y Vignoli, 2016.

${ }^{20}$ Cada número comenzaba con una redacción la cual consistía en una nota elaborada colectivamente que expresaba los pensamientos, sentires y tomas de posición del conjunto editorial. Ninguna de estas notas fueron acompañadas de firma.

${ }^{21} I D E A$, año I (13 de abril de 1919), núm. 1, p. 1.
} 
que reclama del educador virilidad y energía que lo habiliten para formar corazones nobles y rectos que nada contamine ni malee". ${ }^{22}$

Entre sus puntos fundamentales no se propusieron interferir en la designación de los funcionarios encargados del gobierno escolar. Más bien vieron con preocupación las lesiones que provocaban las leyes, reglamentos y disposiciones sobre "los delicados intereses de la escuela y de la educación". Es por ello que reclamaron la creación de un "órgano autónomo encuadrado en las normas de justicia, moralidad y delicadeza profesional" amparados por una ley que regulase el ingreso y la estabilidad del "maestro" de tal modo "que no quede su suerte librada a la voluntad de sus jefes, sujetos como todo lo humano a pasionismos (sic) y debilidades". ${ }^{23}$

Recordemos que para ese momento, el surgimiento de la agrupación IDEA, había colisionado con el funcionario responsable de la Dirección General de Escuelas de la provincia. Enrique Julio, mediante carta ${ }^{24}$ dirigida a la nueva agrupación, calificó a IDEA como "grupo limitado", "especie de logia irrepresentativa" y carente de legitimidad entre las/los maestras/os de la provincia. Se refería a la existencia de la Asociación de Maestros como el genuino organismo de representación mayoritaria del magisterio, razón por la cual no se aceptaba a la naciente agrupación. Los argumentos utilizados para justificar su decisión los remitió a los puntos 2 y 3 de las bases fundacionales de IDEA y advirtió que sus principios llevarían a la anarquía del sector y atentarían contra sus socios. Referido a IDEA, dirá que:

“...no pueden, sin llevar a la anarquía a la misma clase que Uds. quieren defender, constituirse en jueces para expulsar a compañeros de agrupación que hubieran faltado a un juramento de reserva absoluta, reserva que no cuadra a maestros que tienen la misión de proclamar la verdad, la justicia y la libertad a los cuatro vientos, con esa abnegación que al encarnarse en el espíritu de Sócrates primero y de Jesús después, hizo de los dos los más grandes maestros de la humanidad". ${ }^{25}$

Para finalizar la carta, Enrique Julio invitaba a que la agrupación presentara sus "ideales" ante el espacio público "a la luz del día, en el salón, en la calle o en la plaza pública" en clara alusión a su supuesto accionar secreto.

\footnotetext{
22 IDEA, año I (13 de abril de 1919), núm. 1, p. 1.

${ }^{23}$ IDEA, año I (13 de abril de 1919), núm. 1, p. 1.

${ }^{24}$ Con fecha del 20 de marzo de 1919 e incluida entre las notas del primer número de IDEA.

${ }^{25}$ IDEA, año I (13 de abril de 1919), núm. 1, p. 2. Resaltado en el original.
} 
La contestación de IDEA dirigida al "Jefe superior de la enseñanza" se realizó a los pocos días. ${ }^{26}$ La carta no pretendió entrar en controversia, aludiendo a que ello desvirtuaría las tendencias "altruistas, nobles y encuadradas en las normas de corrección y gentileza inherentes a una agrupación cultural que descarta personalismos, que no tiene bandera política y que inscribe en su estandarte como lema: 'respeto, verdad, unión, justicia, fe, entusiasmo, lealtad y patriotismo'".$^{27}$

A continuación se dispusieron responder las acusaciones realizadas por el gobierno escolar. El primer punto tratado por las maestras aludía al supuesto carácter ilegal de la agrupación (acusada de logia y de actuar en las sombras). En su defensa, argumentaron que hacían uso legítimo del derecho de reunión y asociación contemplado en la Constitución provincial, que no pretendían dividir al gremio ya que en su mayoría eran socias de la Asociación de Maestros y habían participado mancomunadamente de los pedidos de reglamentación realizados a la DGE, los cuales no fueron atendidos por los funcionarios escolares. Sin embargo, ante la acusación realizada por Enrique Julio, la discusión comenzó a envolverse de argumentos religiosos sin que por ello se revistiera de un concierto de citas doctrinales. Tal discurso religioso fue utilizado con la intención de dotar de mayor autoridad su propio accionar:

"Sócrates y Jesús [...] se dirigen a todos para extender y propalar sus doctrinas; pero se vinculan íntimamente con muy pocos [...] y forma con ellos un todo armónico. Y el Divino Maestro que con doce apóstoles revoluciona al mundo y extiende de polo a polo su doctrina [...], que resiste la acción de los siglos, [...] que los hace amigos y hermanos, siente aún el dolor de haber dado calor en su pecho al Judas Iscariote que lo besa y lo vende". ${ }^{28}$

La reserva a los socios a la que refieren en el punto 2, obedecía a los acuerdos que con antelación debían darse en la agrupación antes de su publicación. El silencio, durante un lapso de tiempo, se realizaba para evitar "malos entendidos y tergiversaciones". Con esa "norma" y "línea de conducta", las maestras buscaron reafirmarse en Jesucristo. Así para darle autoridad a su accionar y cierto carácter sacrificial, dirían: “Él mismo [...] azotado, coronado de espinas, insultado, envolvía en firme reserva su misión y personalidad cuando respondía a las impacientes preguntas de sus jueces: 'yo soy el que soy,

\footnotetext{
${ }^{26}$ Fechada el día 24 de marzo de 1919 e incluida en el primer número de la revista IDEA, año I (13 de abril de 1919), núm. 1, p. 3.

${ }^{27}$ IDEA, año I (13 de abril de 1919), núm. 1, p. 2.

${ }^{28}$ IDEA, año I (13 de abril de 1919), núm. 1, p. 3.
} 
y el que es, me envía'”. Al sacrificio lo invisten de un horizonte misional, en el que "cada asociado [es] un apóstol" ${ }^{29}$

En referencia a la "justa causa" que las agrupaba, admitían la importancia que revestía otorgar carácter público al conflicto, asunto al que hacía referencia Enrique Julio. "No obramos en la sombra, Señor Director; no tememos la luz, porque son puros nuestros pensamientos, plausibles nuestros ideales, rectos nuestros medios". ${ }^{30}$

Sin embargo fue elocuente la postura de IDEA al considerar que el ámbito indicado para sus reclamos no era "la plaza pública" ya que, entendían se trataba de un espacio usufructuado por "políticos de todos los matices" y "sucursal de los comités". En cambio, se mostraban dispuestas a reunirse en "teatros y centros sociales que han de abrir gustosos sus puertas al educacionista" y mediante el uso de formas más mesuradas "haciendo que se imposte en sus salones la reposada y serena voz del educador, que conocida así por lo más culto de la sociedad, vaya ganándose esa dignificación que le corresponde y que no debe dignamente esperar que se le conceda como una gracia". ${ }^{31}$

Numerosas investigaciones, ya clásicas, se han referido a la delimitación y ocupación del espacio público y privado según el género (varón/mujer) y su vinculación a la legitimidad social para esta época histórica (Morgade, 1997; Yannoulas, 2007; Barrancos, 2007; Lobato, 2007). En la cita anterior, se pone en evidencia la utilización de espacios públicos diferenciados. La plaza pública habitada por varones que arengan y se organizan políticamente; y otros, teatros o centros sociales, más acordes con las formas mesuradas de las educadoras. Esta diferenciación no nos parece insignificante ya que, si bien podría afirmarse que la "mesura" no está íntimamente atada a una cualidad del género femenino, la formulación de la respuesta podría obedecer a los recatos culturales que demarcaban la ocupación de lugares más legítimos que otros para ser habitados por maestras mujeres. Como tampoco podríamos decir sin más, que las formas mesuradas hacen referencias a una cultura propia de la élite político-intelectual de la época, sin embargo, nos parece interesante remarcar cierta reserva "elitista" en relación con la búsqueda del reconocimiento de la dignidad por lo más "culto de la sociedad". Por lo pronto, sí afirmaremos que no se desprenden de su discurso signos identificatorios con las clases populares y notamos cierta tendencia elitista en sus enunciados discursivos.

El asunto no terminó allí y el conflicto cobró estado público. Los principales diarios comerciales de la provincia de Mendoza y de Buenos Aires

\footnotetext{
${ }^{29}$ IDEA, año I (13 de abril de 1919), núm. 1, p. 3.

${ }^{30} I D E A$, año I (13 de abril de 1919), núm. 1, p. 3.

${ }^{31} I D E A$, año I (13 de abril de 1919), núm. 1, p. 3.
} 
brindaron cobertura y publicaron los reclamos docentes. ${ }^{32}$ Desde el primer número de IDEA las maestras continuaron con denuncias tendientes a poner en evidencia la situación de vulnerabilidad en la que se encontraban ante un poder gubernamental que no parecía tener límites. Ellas demostraban no estar dispuestas a silenciar los "muchos vejámenes" a los que estaban siendo sometidas. La "timidez" con que realizaban los reclamos se basó en una situación deprimente para el/la maestro/a "quien en forma individual no eleva sus quejas por no captarse enemigos siempre molestos por pequeños que sean". Es por ello que reiteraban la necesidad urgente de creación de una ley de educación que reglamentara la tarea docente y la alejara de los particularismos e "idiosincrasia particular de cada Director General de Escuelas". Dicha ley era fundamental para evitar la arbitrariedad e ilegalidad en las designaciones y bajas de los cargos docentes. Además, perseguían el respeto por los escalafones y el pago de salarios adeudados por el Estado. Dinero, con el que se atendieron otras necesidades y no la regularización de sus deudas.

Por fuera de la composición mayoritariamente femenina de la agrupación, no surgieron diferencias programáticas explícitas con su antecesora, la Asociación de Maestros de la provincia. Las maestras agrupadas en IDEA entendían que "la lucha" sería abnegada, individual, como deber cívico, y constitutiva a la vida. No hacían mención a medidas de lucha propias del movimiento obrero, tales como: huelgas, manifestaciones públicas, boicot $u$ otra medida de fuerza. Esto podría deberse a su consideración de ser "los más preparados para el progreso social", "cultos" y "civilizados" de la sociedad y, por ello, no recurrir a medidas más enérgicas propias del sector obrero.

La protesta se hizo presente, bajo formas más familiarizadas con el derecho al reclamo pero ni la huelga, ni cualquier otra medida de fuerza apareció mencionada. Su lucha se centró en torno a la búsqueda de reconocimiento gubernamental de una agrupación cultural con aspectos gremiales. Las principales herramientas utilizadas para el logro de su reconocimiento fueron el diálogo y la negociación (fallida) con los poderes públicos. La confrontación con el gobierno escolar, surgió a partir de las divergencias de criterio y se realizó mediante intercambios epistolares, formales, respetuosos y mesurados.

\footnotetext{
${ }^{32}$ Entre las principales prensas provinciales se destaca el diario comercial de mayor tirada en la provincia, Los Andes, fundado en 1883. Se caracterizó por no responder a ninguna facción política, aun así, mostró simpatía y dio cobertura a las acciones colectivas dirigidas por IDEA y MU. La Palabra, órgano de la Unión Cívica Radical y La Montaña, prensa ultra lencinista, apoyaron a sus funcionarios y organizaciones oficialistas como la Unión Mendocina de Maestros. El Socialista, órgano del socialismo, apoyó los reclamos docentes. Los diarios nacionales, La Nación, también brindó cobertura y se mostró favorable a los reclamos docentes. El diario La Prensa, en sus inicios mantuvo una posición crítica ante la ingreso de MU a la FOP y la FORA, sin embargo ante el accionar represivo llevado a cabo por el lencinismo durante las huelgas generales, su posición fue la de denuncia y favorable al conflicto gremial.
} 
Los configuradores de sentido y de autoidentificación giraron en torno al orden religioso con pretensiones de ambos bandos de ocultar el carácter político que el conflicto iba adquiriendo. Si bien las discusiones no revistieron un carácter doctrinal, si operaron como los fundamentos para un tipo de acción política determinada. La experiencia organizativa de este grupo pequeño, se hacía eco de los reclamos de un magisterio, mediante la apelación a un discurso en cuya base se ubicaban como víctimas del "pasionismo" y "capricho" de los funcionarios encargados de la educación. De allí que sus formas de lucha tuvieran más que ver con el pedido de reconocimiento oficial pues se ubicaban en una posición de debilidad y subordinación ante el gobierno. Siguiendo el análisis que Adrián Ascolani realizó sobre la distintas conformaciones del gremialismo docente en Argentina durante las primeras décadas del siglo XX, compartimos, de modo general, varios de los factores que también contribuían a esa debilidad: "la concepción mesiánica heredada del normalismo por la cual se identificaba la función docente como una suerte de sacerdocio laico; la composición mayoritariamente femenina del magisterio, y que se trataba nada menos que de un gremio sin peso electoral propio, pues la mujer carecía del derecho al sufragio" (Ascolani, 1999). La persistente identificación a una misión sagrada llevada adelante por sujetos/as que se autoconsideraban "apóstoles" generaba una particular forma de articular los reclamos. A modo de ejemplo, recurrimos a la siguiente cita:

"El maestro de escuela y el militar se pertenecen a la patria; al recibir su título y al empuñar la espada, han ofrendado su 'yo' ante aras y ese 'yo' debe estar bien resguardado para evitar su menguanza. Como argentinos, no queremos ni imaginar lo que valdría una patria si sus militares y educadores, traicionando el apostolado que abrasamos (sic), depusieran su ' $\mathrm{yo}^{\prime \prime}$ '. 33

Si bien es muy llamativa la analogía entre el maestro de escuela y el militar, lo que nos interesa recalcar aquí es la estructuración del concepto patria asentado sobre los valores apriorísticos del apostolado. Lo cual supuso que las funciones establecidas para el "maestro de escuela" debían estar en concordancia a objetivos mayores a los de su función (estrictas reglas de conducta, portadores del progreso social y de lo más culto de la sociedad, etc). Dichas valoraciones se hacían presente al momento de articular los reclamos sectoriales, es decir que el apostolado y la misión sacerdotal podían dotar de fundamento y potenciar la protesta en busca de legitimidad social, pero también podía advertirse la debilidad que esa forma de protesta adquiría para el sector, debido a una formulación de objetivos siempre mayores (desmedidos) que ese mismo carácter sagrado le otorgaba. La resultante es lo que Enrique

${ }^{33}$ IDEA, año I (28 de abril de 1919), núm. 2, p. 11. 
Garguin ha denominado "ambigüedad constitutiva del magisterio" que se hizo patente en la generalidad de los reclamos gremiales docentes:

“...un 'sacerdocio', que adquiría fuerza de 'deber' más allá de la contraparte salarial; en tanto que deber, exigía dedicación y sacrificios, con los que perdía fuerza la reivindicación económica. Esta ambigüedad simbólica ayuda a explicar su difícil relación con el Estado empleador, que también encontraba fundamento en su específica relación con ese Estado: los poderes -e individuos- a los que debían dirigirse en sus reclamos eran en no pocas ocasiones los mismos que les habían dado los puestos de trabajo" (Garguin, 2014: 171-172).

Situación de debilidad que colocaba en un lugar particularmente riesgoso al sector docente, ya que al constituirse como oposición corrían el peligro de exclusión del sistema educativo debido a la dependencia que la carrera docente tenía del poder político, la forma centralizada del gobierno y la administración de la educación.

En breve, entre los días 25 y 28 de abril, las integrantes de IDEA y agremiadas/os a MU fueron suspendidas sin goce de sueldos por tiempo indeterminado, bajo amenaza de cesantía si continuaban con sus actividades. Este accionar gubernamental no tardó en desatar una serie de transformaciones de amplio espectro que a continuación pasaremos a analizar.

\section{Multiplicar: "Toda piedra forma pared"}

Ante las medidas tomadas por Enrique Julio, IDEA procedió a manifestar su repudio. El Director General de Escuelas “...posee nada menos que la suma del poder público". Hace uso frente a la inexistencia de una Ley de educación de: "ubicar, nombrar, trasladar, suspender y exonerar a los miembros del personal docente [...] con la deliberación de su único y decisivo impulso. Sus determinaciones son inapelables". Los maestros se encuentran "supeditados al criterio exclusivo de un gefe (sic) [...] [con] atribuciones omnímodas" ${ }^{34}$

La ruptura del diálogo, las suspensiones y cesantías abrieron para el gremio un nuevo menú de estrategias que, en primera instancia, consistió en el llamado urgente a la unidad del gremio, "toda piedra forma pared". ${ }^{35}$

"El espíritu del maestro se revela (sic) ante el autoritarismo despótico de sus jefes, su corazón late al unísono ante la inmerecida ofensa que se le infiere y cual impetuosa lava de

\footnotetext{
${ }^{34}$ IDEA, año I (28 de abril de 1919), núm. 2, p. 11.

${ }^{35}$ IDEA, año I (28 de abril de 1919), núm. 2, p. 12.
} 
potente volcán se desborda toda amargura acumulada en meses y meses de humillaciones y vejámenes". ${ }^{36}$

A partir del tercer número (13 de mayo de 1919) el reclamo se articuló sobre otras prioridades más relacionadas a la defensa del empleo, la reincorporación de las maestras cesanteadas, el pago a término de los salarios adeudados y la denuncia del aumento del costo de la vida. Esta reconfiguración en sus reclamos por derechos y aspiraciones de justicia, las/los acercaron a experiencias sociales vinculadas al mundo del trabajo y sus formas de lucha lo que implicó modificaciones profundas en las formas organizativas y el inicio de un nuevo proceso identificatorio con la clase trabajadora.

Las formas de acción fueron severamente alteradas. Ya no solo velaban por la dignidad del maestro sino que llamaban a su conquista:

“Comprende el educador que por si mismo debe conquistar la dignificación que se le promete y que no puede recibir como dávida (sic) generosa [...]. A la fuerza, no otra cosa que la fuerza podrá oponerle. Por eso se sindicaliza, uniendo en fuerte cadena los sueltos eslabones de su personalidad gremial. [...] es una unidad múltiple. Careciendo de una ley que lo proteja, sanciona por si mismo la de su solidaridad, [...] para defender su pan que el capricho de un solo hombre puede arrebatarle en un momento dado; para garantir su independencia, para destacar su personalidad". ${ }^{37}$

Las identificaciones religiosas también sufrieron transformaciones, ya no se trató de Jesucristo, sino de Lázaro o el esclavo o el paria: “El esclavo que rompe sus cadenas, el paria que se torna hombre, el Lázaro que abandona radiante el infecto sepulcro al oir la voz del progreso que con armoniosa sonoridad le dice ‘¡Levántate y anda!'”. ${ }^{38}$

No hay referencias a la palabra patria, se ausenta el pedido a las autoridades del poder público y surge el reconocimiento del aplauso de la opinión junto a la alianza con los obreros. La palabra justicia es reiterada permanentemente y junto a ella la apelación al uso de la fuerza legítima frente al despotismo gubernamental.

IDEA saludaba acaloradamente la creación de MU a quienes entendían como compañeros con el afán de "[aportar] a esa obra común todo su entusiasmo" y proponían transformar su revista en el "vocero de las aspiraciones colectivas". A continuación, daban cuenta de los apoyos extragremiales recibidos y de la alianza con el sector obrero. "Maestros Unidos

\footnotetext{
${ }^{36}$ IDEA, año I (13 de mayo de 2019), núm. 3, p. 19.

${ }^{37}$ IDEA, año I (13 de mayo de 2019), núm. 3, p. 19.

${ }^{38}$ IDEA, año I (13 de mayo de 2019), núm. 3, p. 19.
} 
se ven apoyados por la opinión, sostenidos por la mano amiga del obrero, alentados por la adhesión entusiasta que hasta ellos llega de distintos puntos de nuestra República" ${ }^{39}$

MU ingresaba de manera inmediata a la Federación Obrera Provincial (FOP) y a nivel nacional a la FORA. Así se veía reflejado en la revista:

"El individuo aislado, hoy menos que nunca, nada puede y nada significa. La fuerza, el instinto social reside en la colectividad". [...] "El instinto social de integración ha ido más lejos aun organizando la unidad entre todos los gremios en una institución que en nuestro país representa la Federación Obrera". [...] "[La] Federación Obrera Provincial le ofreció expontánea (sic) y generosamente su adhesión incondicional: el gremio por unanimidad decidió aceptarla". ${ }^{40}$

La adhesión a la FOP-FORA sindicalista, no fue entendida como una simple unidad de acción ante el conflicto, sino que respondía a cambios en la percepción y subjetividad de quienes componían la agrupación y el nuevo sindicato docente. En nota titulada "Agremiación sindical del magisterio" afirmaban lo siguiente: "Al hacerlo, no obedeció solo a las dificultades del momento, sino a las fuerzas de defensa social que hoy unen con vinculación estrecha a los proletarios de la intelectualidad con los obreros de los oficios" ${ }^{41}$

Esta toma de posición por parte de las/los agremiadas/os del magisterio, como proletarios del intelecto, reconfiguraba la manera en que se reconocían como parte de la clase trabajadora. La estrategia de lucha, las alianzas propuestas y las formas de protesta adquirieron un sentido muy distinto al que con antelación se habían propuesto. El principio de solidaridad de clase se antepuso ante cualquier otro criterio, lo cual implicó priorizar la defensa de las/los trabajadores/as en su conjunto y renunciar a fijar prerrogativas que dividieran al movimiento. Una de las condiciones fundamentales desde la cual se efectuó el vínculo de solidaridad tuvo por objetivo evitar el divisionismo interno por causas políticas y/o religiosas. Para ello reglamentaron la "prescindencia absoluta de ideas políticas, de tendencias sociales determinadas que no se refieran a la solidaridad gremial de todos y a la defensa común, y libertad de creencias religiosas" ${ }^{42}$

Estas premisas les permitieron un cierto grado de independencia relativa con las cuales tomar las riendas del conflicto contra su empleador. Definir mejor al adversario y enfocar y adecuar las formas de lucha. El movimiento del sector docente mediante su ingreso a la FOP-FORA pudo aglutinar por primera vez a

${ }^{39}$ IDEA, año I (13 de mayo de 2019), núm. 3, p. 19.

${ }^{40} I D E A$, año I (13 de mayo de 2019), núm. 3, p. 20.

${ }^{41} I D E A$, año I (13 de mayo de 2019), núm. 3, p. 20.

${ }^{42}$ IDEA, año I (13 de mayo de 2019), núm. 3, p. 20. 
trabajadoras/es de mundos heterogéneos en cuanto a su función (músculo/intelecto), pero más homogéneo en cuanto a compartir la experiencia de la explotación.

Esto llevó a establecer, como ya mencionamos, formas enérgicas de lucha. La primera huelga del magisterio mendocino abrazaba la forma de lucha obrera, no obstante las particularidades en cuanto a su rol y función social se hicieron presentes de la siguiente manera:

"Las organizaciones obreras en sus movimientos persiguen para el logro de sus fines afectar la economía del capital. Detienen las industrias, paralizan los transportes, impiden el comercio; pero qué podrían perseguir con paralizar expresamente el desembolvimiento (sic) normal de la enseñanza?" 43

El interrogante final expresaba una doble preocupación, por un lado, el grado de efectividad de la huelga docente, pues efectivamente no paralizaba el flujo normal del capital; y por el otro, cómo la interrupción de la educación afectaría principalmente a las/los hijas/os de las/los trabajadoras/es, sus potenciales aliadas/os.

"Sus hijos, que son la mayoría de los concurrentes a la escuela pública serían los más perjudicados. $\mathrm{Y}$ es preciso [...] conocer el deseo intenso de cultura que anima a las clases obreras [...]. Los delegados de la Federación así lo han expresado en forma expontánea (sic) y solemne en [...] asamblea [conjunta con los/las maestros/as]". ${ }^{44}$

Esta adhesión también dejaba sobre tablas la preocupación compartida por los delegados de la FOP. Ellos debieron justificar la preocupación conforme a prescripciones de género (masculino), esgrimiendo argumentos que los vincularan a los deseos intensos de cultura demandados por la organización familiar. Su demanda parece situarlos en una posición favorable ante el movimiento, como hombres responsables y celosos custodios del bienestar familiar. Con altísimos riesgos de que los poderes públicos impugnaran al conjunto del movimiento, aun así, “apelaban al favor de una opinión pública para con su causa y cuestionaban, con un argumento creíble y contundente, el estereotipo de agitador profesional, como principal organizador de los movimientos huelguísticos" (Palermo, 2016: 101). ${ }^{45}$

\footnotetext{
43 IDEA, año I (13 de mayo de 2019), núm. 3, p. 20.

${ }^{44}$ IDEA, año I (13 de mayo de 2019), núm. 3, p. 20.

45 Si bien la autora analiza el caso de la primera huelga general ferroviaria acaecida en 1917, hemos incluido, superficialmente, las categorías trabajadas por la investigadora, ya que nos sirven para pensar en nuestro conflicto social desde una perspectiva análoga. En próximos trabajos procuraremos su profundización analítica y revisión categorial.
} 
Esa doble preocupación (la interrupción de la educación ligado a cierto paternalismo ejercido por los delegados de la Federación) tuvo como corolario que las maestras en huelga decidieran continuar con el dictado de clases, no en las escuelas, sino en los locales sindicales y en sus hogares durante todo el transcurso del conflicto para que los/las hijos/as de la clase obrera no perdieran el año escolar ${ }^{46}$. Esta medida, sin duda, reforzó aún más la vinculación con el movimiento obrero organizado, pero también con las familias de la comunidad. Como contraparte, los delegados de la FOP y sus familias aseguraban la no asistencia de sus hijos/as a las escuelas mientras durara el conflicto. Cierto maternalismo docente y paternalismo obrero se hacían presente al interior del movimiento demostrando la necesidad de cierta adecuación de las formas clásicas y masculinizadas de lucha.

"El obrero, padre en su mayoría de los educandos a él confiados, se identifica con el maestro, hace propio el ultraje inferido a su dignidad y viéndole víctima de la fuerza de un poder que nada regula ni nada limita, le ofrece la fuerza de su solidaridad gremial". ${ }^{47}$

MU e IDEA, aclaraban que el modo de vinculación y organización en el que se sellaba la alianza con el movimiento obrero organizado se realizaba con fines reformistas, no disolventes y articulados sobre el derecho a la vida:

"Sobre esas bases el gremio organiza su sindicato. No va contra nadie, no se propone destruir las instituciones ni cambiar el orden social. [...] Pero quiere [...] reivindicar sus derechos a la vida [...] mejorando al mismo tiempo las condiciones [...] de la enseñanza popular, medio [...] para la reciprocidad que debe a la clase obrera [...] generosa y valiente a su lado en rudo trance de amarga prueba". ${ }^{48}$

Para finalizar este apartado, quisiéramos retomar lo sucedido durante la manifestación callejera del 29 de abril de 1919. El magisterio en huelga contó con el apoyo de la FOP, pero fundamentalmente de sus estudiantes que marcharon junto a él por las calles mendocinas.

"Los niños de las escuelas organizan expontáneas (sic) manifestaciones que recorren la ciudad, pidiendo revocación de las medidas disciplinares y el pago de los ocho meses de que a sus maestros se adeuda. Cúlpase a los maestros de agitadores y

\footnotetext{
46 "Los maestros, de acuerdo con lo dispuesto en la última asamblea [...], hoy dieron clase a sus alumnos en diferentes sitios públicos de la ciudad y en algunos locales cedidos a tal efecto. El lunes continuarán las clases en la misma forma y con el mismo horario cumplido hoy". "El Conflicto del Magisterio", en Los Andes (2 de mayo de 1919).

${ }^{47}$ IDEA, año I (13 de mayo de 1919), núm. 3, p. 22. Resaltado en el original.

${ }^{48}$ IDEA, año I (13 de mayo de 1919), núm. 3, p. 20.
} 
decrétase el cierre total de las escuelas de la ciudad, quedando de hecho en huelga por resolución oficial.

Los alumnos persisten en su actitud con el consentimiento de sus padres, cuando no guiados por ellos mismos" ${ }^{49}$

La represión con armas de fuego y piedras lanzadas desde la terraza del edificio en el que funcionaba el diario ultraoficialista La Montaña, dejaron un saldo de cuatro niños heridos. Al día siguiente, el diario La Palabra, de corte oficialista decía lo siguiente: "niñitos y niñitas, inconscientes, gritando improperios [...] Hoy se alza [la rebeldía] contra la autoridad de la escuela, mañana se alzará contra la del hogar" ${ }^{50}$ Esta cita nos permite delinear al menos dos caracterizaciones realizadas por el lencinismo: 1) El tipo de accionar llevado adelante por el magisterio fue entendido como rebelión contra la autoridad escolar, y 2) el modo en que la manifestación compuesta por una importante cantidad de mujeres y niños/as puso en riesgo la tranquilidad del hogar, desde la óptica de los poderes públicos apeló a la restitución del orden patriarcal para justificar el accionar represivo. Sin haber agotado la exploración de las fuentes disponibles, consideramos que se trata de la primera referencia en la que se hace alusión explícita a un conflicto feminizado. ${ }^{51}$

La intervención federal, el desplazamiento de Enrique Julio de la Dirección General de Escuelas y la restitución de las/los docentes suspendidos y cesanteados fue vivenciada desde IDEA como un rotundo triunfo. Apelaron a una opinión pública favorable y que en términos generales se ubicaba en un sentido diametralmente opuesto al expresado por el diario La Palabra. Así lo sintetizaban en sus páginas:

"Revocada la sentencia vergonzosa, abiertas las escuelas, las tareas educativas se normalizan, con más entusiasmo, con más amor. Los hechos producidos estrecharon los lazos entre maestros y educandos, entre aulas y el hogar y un nuevo período tiene comienzo, período de vida más intensa y más feliz, abierta a nuevas esperanzas, mostrando mayores horizontes, haciendo vislumbrar un mañana mejor, que disipe los tristes recuerdos de una era ya caduca". ${ }^{52}$

Aunque, como anticipamos en la introducción, el conflicto se reabriría con más fuerza al poco tiempo, la articulación de sus reclamos por la demanda de cultura para la familia del hogar obrero cimentó una alianza perdurable entre las/los trabajadores/as. Las transformaciones en el proceso de

\footnotetext{
${ }^{49}$ IDEA, año I (13 de mayo de 1919), núm. 3, p. 21.

${ }^{50}$ La Palabra (30 de abril de 1919). Citado en Richard Jorba, 2014a: 104.

51 Nuestra intención es empezar a historizar esta categoría en referencia al rol de las trabajadoras en dicho conflicto.

${ }^{52}$ IDEA, año I (13 de mayo de 1919), núm. 3, p. 19.
} 
identificación experimentadas por las mujeres maestras organizadas sindicalmente durante el conflicto fortalecieron el vínculo social, del modo más solidario posible y dotaron su causa de una dignidad indiscutible ante su comunidad.

\section{A modo de cierre}

El estudio de la primera fase del conflicto docente analizado a partir de la revisión documental y la incorporación de la revista IDEA nos ha permitido profundizar sobre la percepción que tenía de sí mismo el magisterio antes y después de la primera huelga.

En cuanto a su posicionamiento en la esfera pública mendocina, la agrupación IDEA adoptó diferentes definiciones de sí misma que se visualizan en los primeros números de esta revista. Particularmente podemos percibir una diferenciación entre los números 1 y 2 (13 y 28 de abril respectivamente) y el tercero (13 de mayo), en el que consideramos que su identificación con la clase trabajadora se consolida.

En cuanto a la dimensión de clase hemos podido constatar que en los primeros dos números de la revista IDEA se caracterizaron por un intento de acercar posiciones con la élite político-intelectual y el gobierno con el afán de ser reconocidos como agrupación del magisterio. En la enunciación de sus discursos primaron las formas moderadas, mesuradas y respetuosas hacia la autoridad, y apelaron a las dimensiones, religiosa y nacionalista para afirmarlos sobre bases que le dieran una fuerte legitimidad social. Hemos analizado cómo esas dimensiones, también, debilitaron sus reclamos gremiales y dificultaron la identificación del Estado empleador como su principal adversario.

Sin embargo, esa forma de enunciación se combinó, para luego transmutar, con discursos más progresistas y reformistas, posiblemente por la cercana convivencia con las tendencias sindicalista revolucionaria, socialista y anarquista de la época con las que el gremialismo del magisterio mendocino tuvo contacto. ${ }^{53}$ Esos elementos discursivos más propios del movimiento obrero organizado, con un marcado tono clasista y combativo, irrumpieron pero también fueron matizados. ${ }^{54}$ Esta hegemonía discursiva que circuló durante la totalidad del tercer número de IDEA, fue cobrando forma a medida que fueron transitando por las primeras experiencias de organización sindical y de lucha

53 Para un intercambio entre las tendencias ideológicas mencionadas y el gremialismo mendocino recomendamos la ponencia realizada por Satlari, 2011.

${ }^{54}$ A modo de ejemplo transcribimos el siguiente apartado: "El obrero, hoy más culto de lo que se le supone, sabe bien que á (sic) las aulas no debe llegar el ruido de las pasiones, el eco de los comités ni los principios en que se basan los odios de clase. En el laboratorio de las mentalidades ha de reinar la serenidad más completa [...] el sublime amor a lo bueno, lo justo y lo bello". IDEA, año I (13 de mayo de 1919, núm. 3, p. 22. 
(asambleas, mítines, huelga y manifestaciones callejeras) que las/los llevó a postular una pertenencia identitaria con la clase obrera y sus familias. No obstante, demarcaron diferencias según su rol y función social subdividiéndola entre la del músculo (oficio) y la del cerebro (intelectual), afirmando su pertenencia a la segunda. Los vínculos sociales a partir de la solidaridad de clase afirmaron la alianza y se consolidaron desde los inicios de este largo conflicto que atraviesa la totalidad del año 1919. Asimismo fueron delimitando y construyendo formas particulares para llevar adelante la primera huelga docente junto a otras medidas de fuerza implementadas por el novel sindicato y consensuadas con la FOP.

En cuanto a la perspectiva de género como abordaje -al que consideramos ineludible en un colectivo como el que aquí analizamos- nos abre la posibilidad de comprender todo el conflicto llevado a cabo en 1919 desde otra variable, que habilita múltiples y nuevas lecturas e interrogantes, y que sin duda consideramos enriquece y complejiza el resto de las interpretaciones con las que contamos a la fecha.

En este sentido, primeramente hemos dado cuenta de la composición mayoritariamente femenina en las dos organizaciones seleccionadas: IDEA y MU. Asimismo, nos ha permitido subrayar la diferencia genérica que se dio en las capas dirigenciales del gremio en comparación con su antecesora, la Asociación de Maestros. Conjuntamente, esto ocurría en un marco cívico y legal que consideraba a las mujeres más débiles e incapaces respecto del hombre; cuestión que implicaba una considerable contradicción pues era suya la difícil tarea de educar al futuro ciudadano, al tiempo que a ellas no les eran reconocidas la plenitud de derechos. Ese contexto se agravó por la determinación del gobierno de no pagar al magisterio durante ocho meses su salario sometiéndolo a sufrir penurias extremas; una situación que se había generalizado durante los últimos seis años. Este accionar gubernamental no distinguía colores políticos (conservadores-radicales) y es por ello que no puede menos que relacionarse al supuesto de que por tratarse de un sector feminizado, el salario no contaba como recurso indispensable para la reproducción de la vida. Argumento que reposaba sobre un régimen patriarcal en el que el salario percibido por la mujer trabajadora podía considerarse complemento pero no principal ingreso para el sostén familiar. Consideramos que para el caso de las suspensiones sin goce de haberes por tiempo indeterminado tuvo que operar el mismo principio.

Otro de los rasgos fundamentales analizados fue la ocupación diferenciada del espacio público en el que advertimos una transformación radical. Durante el periodo estudiado, las maestras mujeres eran de las pocas trabajadoras que gozaban de legitimidad social en la realización de sus tareas laborales en el espacio público. Sin embargo la escuela primaria como institución pública fue asimilada como segundo hogar debido a su abrumadora 
composición femenina. La función maternal en el hogar, se trasladó por extensión a la escuela construyendo la imagen de maestra en analogía a una "madre educadora" (Morgade, 1997). De este modo el tránsito del hogar a la escuela y viceversa, significó para la maestra, un pasaje que con el tiempo la sociedad internalizó como "natural". Sin embargo, estas maestras en abierto conflicto con el gobierno escolar dejaban entrever algo más que el simple desacato al principio de autoridad. El hecho de que hicieran uso de espacios públicos tales como teatros o centros sociales para llevar a cabo sus asambleas sindicales en conjunto con los representantes varones de la FOP, implicó un fuerte impacto social para la época, sobre todo si consideramos las prescripciones, conductas y valoraciones morales que pesaban sobre la mujer y sus apariciones públicas. Aun así, esa alianza se afianzó estrechando perdurables lazos entre las maestras y estudiantes, entre las aulas y el hogar obrero consolidando los fuertes vínculos sociales que caracterizó al movimiento. $\mathrm{Y}$ al interior del movimiento obrero, la primera huelga del magisterio, interpeló hasta el substrato masculinizado de las clásicas formas de lucha del movimiento obrero organizado. Las adecuaciones en el modo de lucha asimiladas en el devenir de la huelga nos demuestra hasta qué punto fue interpelada por el género femenino.

Pero el asunto no terminó allí. La presencia pública de las mujeres maestras acompañadas de sus estudiantes en manifestaciones callejeras feminizaron el conflicto, lo cual implicó la determinación de ciertos dispositivos represivos por parte del gobierno lencinista para el restablecimiento del orden patriarcal sobre todo en lo concerniente a la pacificación del orden privado, es decir, la restitución de la tranquilidad al hogar. Sindicadas de anarquizar al gremio docente, primero, y al régimen escolar después, estas maestras fueron consideradas una amenaza por el gobierno escolar, portadoras de la insubordinación y agitadoras sociales con capacidad de movilizar no solo a su sector, sino a sus alumnos/as quienes las acompañaron junto a sus familias. A pesar de todos los intentos por extirparlas del sistema y fracturar el fuerte vínculo social, a este grupo de 14 se le sumaron cientos de personas. Víctimas de esas "humillaciones y vejámenes", en sus empeños cotidianos por sobrevivir, hombres y mujeres definieron sus derechos y articularon nociones de lo justo imbricados en las experiencias sociales (Andújar, 2016: 10). El hecho de que estas/os trabajadoras/es reclamaran el pago de sus salarios, mejoras laborales y defendieran su derecho al trabajo, en nombre de una justicia que no parecía condecirse con el género femenino, fue configurando un principio ético solidaridad de clase y de género- desde el cual legitimar la protesta ante el conjunto social mendocino. Vinculación que perduró de manera inquebrantable durante todo el largo conflicto de 1919.

En el análisis de estos primeros números de IDEA damos cuenta de la constitución del gremio de maestras y de su proceso de configuración 
identitaria y de clase. Si bien como anunciamos, esta prensa se compone de 21 números, nos resulta fundante el análisis de este primer momento en el que logran una identificación con la clase obrera, aunque con matices propios de su condición de mujeres, trabajadoras del intelecto. Consideramos que a partir de aquí la impronta feminizada es más clara, tanto en sus estrategias de lucha como así también en las respuestas del Estado, en su búsqueda de consolidación del orden patriarcal establecido. Instancias estas que habilitan próximos análisis en los que se dé cuenta de la importancia de la huelga del magisterio de 1919.

\section{Bibliografía citada}

Alvarado, Mariana (2016). “El Alegato de Florencia Fossatti: claves para una historia de las ideas pedagógicas desde una epistemología feminista", en Anuario de historia de la educación, Buenos Aires, vol. 17, núm. 2.

Andújar, Andrea et al (2016). Vivir con lo justo: estudios de historia social del trabajo en perspectiva de género. Argentina, siglos XIX y XX, Rosario: Prohistoria.

Ascolani, Adrián (1999). “¿Apóstoles laicos, burocracia estatal o sindicalistas? Dilemas y prácticas del gremialismo docente en Argentina (1916/1943)", en Anuario 1998/1999, Sociedad Argentina de Historia de la Educación, Buenos Aires, núm. 2, pp. 88-89.

Barrancos, Dora (2007). Mujeres en la sociedad argentina: una historia de cinco siglos, Buenos Aires: Sudamericana.

Caldo, Paula y Vignoli, Marcela (2016). “Dossier. Mujeres en la historia de la educación (parte I)", en Anuario de historia de la educación, Buenos Aires, vol. 17, núm. 2.

Crespi, Graciela (1997). "La Huelga docente de 1919 en Mendoza”, en Morgade, Graciela (comp.) Mujeres en la educación. Género y docencia en Argentina 18701930, Buenos Aires: Miño y Dávila.

De la Vega, Jacinto (1997). Mendoza 1919: ¡Huelga! El nacimiento de la sindicalización del magisterio mendocino, Mendoza: Ediciones culturales de Mendoza.

Dufour, Ana Luisa y Mazzei, Stella (2007). “Conflictos gremiales docentes en Mendoza (1919-1972)", en Roig, Arturo y Satlari, María Cristina (comps.) Mendoza, identidad, educación y ciencia, Mendoza: Ediciones culturales de Mendoza.

Finocchio, Silvia (2009). La escuela en la historia argentina, Buenos Aires: Edhasa.

Garguin, Enrique (2014). "Intersecciones entre clase y género en la construcción social del magisterio. La Asociación de Maestros de la provincia de Buenos 
Aires durante las primeras décadas del siglo $X X^{\prime \prime}$, en Adamovsky, Ezequiel; Visakovsky, Sergio y Vargas, Patricia (comp.) Clases medias. Nuevos enfoques desde la sociología, la historia y la antropología, Buenos Aires: Ariel.

Lacoste, Pablo (1995). La Unión Cívica Radical en Mendoza y en la Argentina, 18901946, Mendoza: Ediciones Culturales, Mendoza.

Lobato, Mirta Zaida (2007). Historia de las trabajadoras en la Argentina, Buenos Aires: Edhasa.

Luis, Natalia (2015). "Legislación social lencinista: La sanción de leyes de regulación laboral en 1918", en VI Jornadas interdisciplinarias de investigaciones regionales. Enfoques para la historia, Mendoza: CCT-CONICET.

Marianetti, Benito (1970). Las luchas sociales en Mendoza, Mendoza: Ediciones CUYO.

Mellado, Virginia (2007). “La Liga Patriótica Argentina. Una aproximación a las redes asociativas de los elencos políticos y culturales de Mendoza (1919-1930)", en Entrepasados, Buenos Aires, vol. 16.

Morgade, Graciela (1997). Mujeres en la educación. Género y docencia en Argentina, 1870-1930, Buenos Aires: Miño y Dávila.

Olguín, Dardo (1965). José Néstor Lencinas. Historia y mito, Mendoza: Vendimiador.

Palermo, Silvana (2016). “El derecho a mantener el hogar: las demandas obreras en la gran huelga ferroviaria desde una perspectiva de género. Argentina, 1917", en Andújar, Andrea Vivir con lo justo: estudios de historia social del trabajo en perspectiva de género. Argentina, siglos XIX y XX, Rosario: Prohistoria.

Richard Jorba, Rodolfo (2014a). “El relato populista y la realidad. La primera y mayor huelga del magisterio mendocino, 1919", en Rodríguez Vázquez, Florencia (coord.) Gobernar la provincia del vino. Agroproducción y política entre la regulación y la intervención (Mendoza 1916-1970), Rosario: Prohistoria.

Richard Jorba, Rodolfo (2014b). “Los orígenes del fenómeno populista en Mendoza. El gobierno de José Néstor Lencinas, 1918-1920", en Rodríguez Vázquez, Florencia (coord.) Gobernar la provincia del vino. Agroproducción y política entre la regulación y la intervención (Mendoza 1916-1970), Rosario: Prohistoria.

Satlari, María Cristina (2011). “Organizaciones obreras en Mendoza en el primer cuarto del siglo XX: Anarquistas, sindicalistas y socialistas. La huelga de maestros como factor aglutinante de las filiaciones de los obreros", en Núñez, Paula (comp.) Miradas Transcordilleranas. Selección de trabajos del IX Congreso Argentino Chileno de Estudios Históricos e Integración Cultural, San Carlos de Bariloche: IIDyPCa, UNRN - CONICET, pp. 632-646. 
Yannoulas, Silvia (1993). “Educar: una Profesión de Mujeres? La Feminización del Normalismo y la Docencia en Brasil y Argentina (1870-1930)", en Estudios pedagógicos, Brasilia, vol. 74, núm. 178, pp.713-738

Yannoulas, Silvia (2007). Educar: ¿una profesión de mujeres?: la feminización del normalismo y la docencia: 1870-1930, Buenos Aires: Kapeluz. 